\title{
Study on the quality of adhesion in the case of 5th class cavities
}

\author{
Studiu asupra calităţii adeziunii în cazul cavităţilor clasa a V-a
}

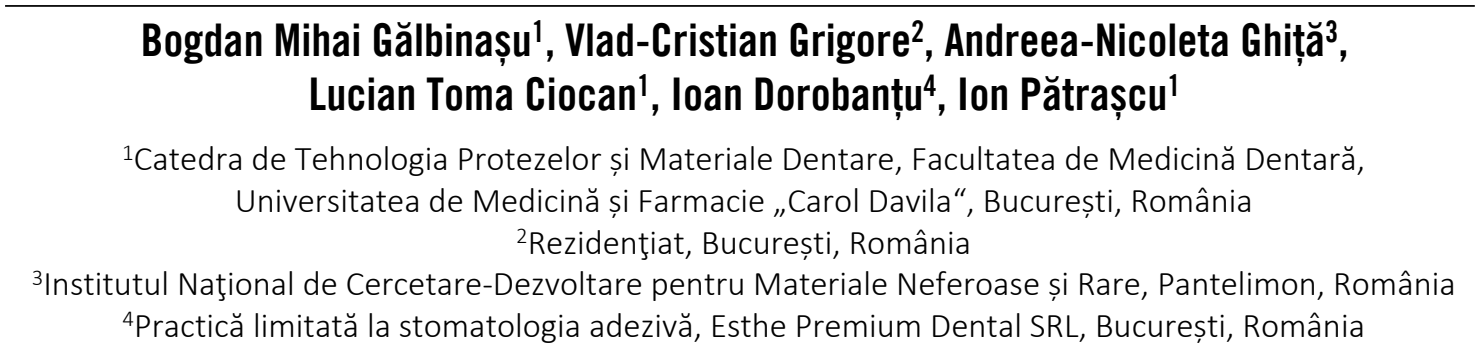

\begin{abstract}
Objective. The aim of the present study is to evaluate the adhesion of the diacrylic composite resins to cementum with or without an intermediate layer of flowable composite.

Materials and method. Standardized class $V$ cavities were made on the vestibular surfaces of 24 maxillary third molars. The cavities were filled with microhybrid (Filtek Z250 - 3M/ESPE), respectively nanohybrid composites (Flltek Z550 - 3M/ESPE), half of these also having an intermediate layer of flowable composite (Gradia Direct LoFlo - GC). All of the specimens were subjected to a thermocycling process $\left(300\right.$ cycles in water of $\left.5^{\circ} / 55^{\circ}\right)$. After the isolation of the teeth with nail polish, they were introduced into $1 \%$ methylene blue for 24 hours. Subsequently, they were embedded in an epoxy resin (EpoThinTM2 - Buehler), polished and sectioned mesio-distally with Beta Grinder/Polisher - Buehler. The sections were selected where the greatest degree of methylene blue penetration was detected to be analyzed by optical polarized light microscopy (Axio Imager A1m - Zeiss).

Conclusion. The composite fillings allow the microinfiltration of the cementum and dentine, leading in time to the possibility of direct restoration failure. Also, the existence of an intermediate layer of flowable composite does not improve adhesion.
\end{abstract}

Keywords: diacrylic composite resins, adhesion, dentine, cement, intermediate layer, microhybrid, nanohybrid

\section{REZUMAT}

Obiectiv. Scopul prezentului studiu este de a evalua adeziunea compozitelor la nivelul cementului, în prezenţa sau lipsa unei obturaţii de bază.

Materiale şi metodă. La nivelul a 24 molari trei maxilari au fost realizate cavităţi standardizate clasa a V-a pe suprafeţele vestibulare. Cavităţile au fost obturate cu răşini diacrilice compozite microhibride (Filtek Z250 - 3M ESPE), respectiv nanohibride (Filtek Z550 - 3M ESPE), jumătate dintre acestea având şi un strat intermediar de compozit fluid (Gradia Direct LoFlo - GC), şi supuse unui proces de termociclare $\left(300\right.$ de cicluri în apă de $\left.5^{\circ} \mathrm{C} / 55^{\circ} \mathrm{C}\right)$. După izolarea dinţilor cu lac, aceștia au fost introduşi în albastru de metilen $1 \%$ timp de 24 de ore. Ulterior, au fost înglobaţi într-o răşină epoxidică (EpoThinTM 2 - Buehler), lustruiţi şi secţionaţi mezio-distal cu ajutorul Beta Grinder/Polisher - Buehler. S-au ales secţiunile unde era surprins cel mai mare grad al penetrării albastrului de metilen pentru a fi analizate prin microscopie optică cu lumină polarizată (Axiolmager A1m - Zeiss).

Concluzii. Obturaţiile de compozit permit microinfiltraţia cementului şi dentinei, ducând în timp la posibilitatea eşecului restaurării directe. De asemenea, existenţa unui strat intermediar din compozit fluid nu ameliorează adeziunea.

Cuvinte cheie: răşini diacrilice compozite, adeziune, dentină, cement, strat intermediar, microhibrid, nanohibrid

\section{INTRODUCERE}

Restaurările directe au avut o evoluţie importantă de-a lungul anilor în încercarea de perfecţionare a materialelor sau a tehnicilor folosite. Deşi nu se poate vorbi încă despre un material ideal, în prezent, răşinile diacrilice compozite sunt o alegere frecventă datorită proprietăţilor estetice şi adeziunii la nivelul smalţului (Fig. 1). 
Principala problemă cu care se confruntă obturaţiile din compozit este prezenţa microinfiltraţiei marginale, fenomen dinamic, care constă în trecerea bacteriilor şi salivei la nivelul interfeţei dinterestaurare. Uneori, acest proces nu este vizibil clinic, însă poate avea drept consecinţe apariţia cariei secundare, hipersensibilitate dentinară, coloraţia marginilor obturaţiei, mergând până la afectare pulpară (1-4). Microinfiltraţia marginală este rezultatul contracţiei de polimerizare din timpul prizei răşinii, atunci când aceasta trece din forma de monomer în cea de polimer, producându-se spaţiul necesar contactului cu mediul bucal. Tehnologiile moderne au redus această contracţie de polimerizare şi, implicit, microinfiltraţia, fără a avea succes însă în eliminarea definitivă a acesteia $(5,6)$.

$\mathrm{O}$ adeziune eficientă la nivelul structurilor dure dentare contracarează şi reduce posibilitatea microinfiltraţiei marginale, însă se poate vorbi despre o adeziune eficientă doar la nivelul smalţului şi, într-o oarecare măsură, al dentinei. Cementul reprezintă o adevărată provocare pentru o sigilare optimă (7). În cadrul cavităţilor clasa a II-a şi a V-a, adesea limita lor apicală depăşeşte joncţiunea smalţ-cement şi astfel este nevoie a se obţine o adeziune puternică la nivelul cementului, obiectiv dificil din cauza structurii acestuia bogată în substanţe organice (8). Studiile au arătat faptul că, la nivelul cementului, în urma demineralizării şi infilttrării cu monomeri răşinici, se obţine o rețea de colagen cu un procent crescut de substanţe organice improprie adeziunii (9).

Tehnicile de restaurare directă cu ajutorul răşinilor diacrilice compozite sunt în continuă evoluţie pentru a contracara fenomenul de microinfiltraţie marginală: reducerea dimensiunii particulelor anorganice, silanizarea acestora, dezvoltarea unor tehnici de fotopolimerizare sau aplicarea unor obturaţii de bază. Compozitele microhibride şi nanohibride, prin particulele de dimensiuni micrometrice şi nanometrice, având un procent de volum de substanţă anorganică mărit, reduc contracţia de polimerizare, îmbinând estetica şi fiabilitatea. În ceea ce priveşte însă superioritatea unuia sau a celuilalt, studiile sunt contradictorii (10-15). Aceeaşi contradicţie se observă şi în privinţa avantajelor oferite de obturaţiile de bază sub obturaţiile de compozit (16-18).

Aşadar, microinfiltraţia marginală rămâne principala cauză a eşecului obturaţiilor din răşini diacrilice compozite, cavităţile situate sub joncţiunea smalţ-cement fiind cele mai susceptibile din cauza adeziunii precare de la nivelul cementului.
Scopul prezentului studiu este de a evalua adeziunea compozitelor la nivelul cementului, în prezenţa sau lipsa unei obturaţii de bază.

\section{MATERIAL ŞI METODE}

\section{Selecţia şi prepararea specimenelor}

În prezentul studiu, s-au utilizat 24 molari de minte maxilari care nu prezentau pe faţa vestibulară carii în zona coletului şi nici fracturi vizibile clinic. După debridare, au fost imersaţi în apă distilată până la momentul preparării.

S-au preparat cavităţi clasa a V-a standardizate pe faţa vestibulară, cu limita apicală la nivelul cementului (Fig. 2). Dimensiunile cavităţilor au fost: $3 \mathrm{~mm}$ mezio-distal, $2 \mathrm{~mm}$ ocluzo-apical şi vestibulo-oral. Pentru acest lucru, s-a folosit iniţial o piatră diamantată efilată pentru a marca joncţiunea smalţcement şi întinderea mezio-distală a cavităţii, apoi o piatră diamantată cu inel verde (diametru 1,8 mm) acţionată de turbină la viteza de 300.000 rpm şi răcire continuă cu apă (Fig. 3). Ulterior, pentru controlul cavităţilor s-a utilizat o sondă parodontală.

Toaleta cavităţii a fost realizată prin uscarea şi degresarea timp de 10 secunde cu o buletă sterilă îmbibată si apoi exprimată de soluţie pe bază de acetonă şi acetat de etil (Hydrol - Septodont).

\section{Realizarea obturatiilor}

Adeziunea s-a obţinut cu ajutorul unui sistem adeziv etch-and-rinse în 2 paşi. Pentru demineralizare s-a utilizat gravarea acidă totală cu acid ortofosforic 32\% (Scotchbond ${ }^{\mathrm{TM}}$ Universal Etchant - 3M ESPE), timp de 30 de secunde la nivelul smalţului şi 15 secunde la nivelul dentinei şi cementului, urmată de spălare timp de 30 de secunde. Excesul de apă a fost îndepărtat cu bulete de vată sterile. Răşina adezivă (Adper Single Bond 2 - 3M ESPE) a fost aplicată cu ajutorul unui aplicator şi fricţionată timp de 15 secunde pe pereţii cavităţii. Ulterior, stratul a fost subţiat cu un jet fin de aer şi fotopolimerizat cu lampa LED. Au fost aplicate două straturi.

Dinţii au fost împărţiţi aleator în 4 grupuri şi restauraţi după cum urmează:

Grup 1 - compozit microhibrid (Filtek Z-250 3M/ESPE) aplicat fără obturaţie de bază (6 dinţi)

Grup 2 - compozit microhibrid (Filtek Z-250 3M/ESPE) aplicat pe o obturaţie de bază din compozit fluid (Gradia Direct LoFlo - GC) cu grosimea de $1 \mathrm{~mm}$ (6 dinţi) 


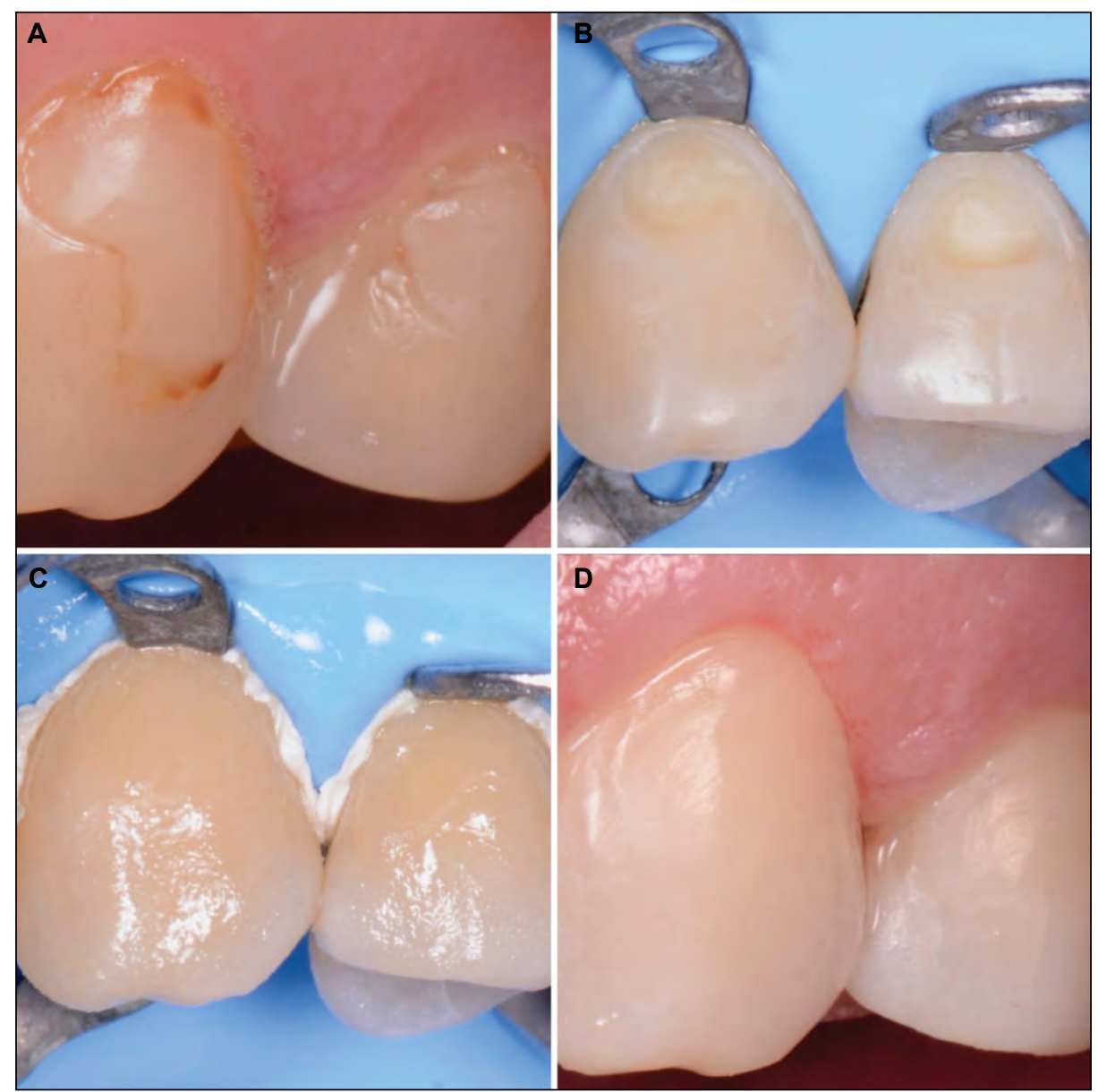

FIGURA 1ABCD. Tratamentul unor leziuni carioase la nivelul coletului cu ajutorul răşinilor diacrilice compozite (Dr. Ioan Dorobanţu)

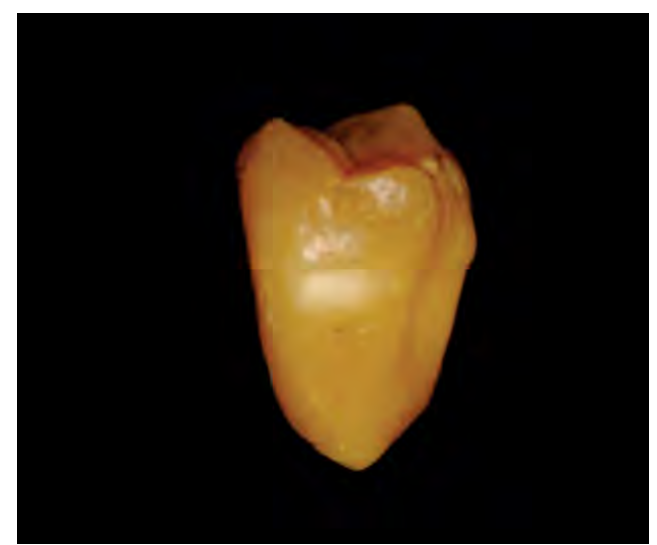

FIGURA 2. Cavitate standardizată

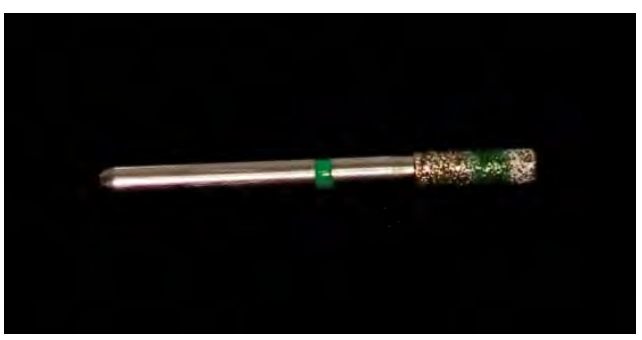

FIGURA 3. Piatra diamantată utilizată la realizarea cavităţilor. S-a realizat un marcaj la $2 \mathrm{~mm}$ de vârf pentru controlul adâncimii preparaţiei
Grup 3 - compozit nanohibrid (Filtek Z-550 3M/ESPE) aplicat fără obturaţie de bază (6 dinţi)

Grup 4 - compozit nanohibrid (Filtek Z-550 $3 \mathrm{M} / \mathrm{ESPE}$ ) aplicat pe o obturaţie de bază din compozit fluid (Gradia Direct LoFlo - GC) (6 dinţi).

Obturaţiile au fost finisate cu gume abrazive montate la piesa contraunghi, la viteze de 30.000 rpm, dinţii fiind apoi depozitaţi în apă distilată pentru o perioadă de 24 ore.

\section{Evaluarea microinfiltraţiei marginale}

Dinţii au fost termociclaţi (500 cicluri de la $5^{\circ} \mathrm{C}$ la $55^{\circ} \mathrm{C}$, cu 10 secunde între cicluri) şi acoperiţi cu două straturi de lac, cu excepţia obturaţiei şi a unei zone de $1 \mathrm{~mm}$ în jurul acesteia. Specimenele au fost imersate complet în albastru de metilen $1 \%$ timp de 24 de ore, recipientele fiind ferite de căldură şi radiaţii solare care ar putea afecta proprietăţile trasorului. După 24 de ore, s-a realizat spălarea cu apă distilată a dinţilor şi uscarea, urmată de înglobarea în răşină epoxidică (EpoThin ${ }^{\mathrm{TM}} 2$ - Buehler), lustruirea şi secţionarea mezio-distală (Beta Grinder/ 


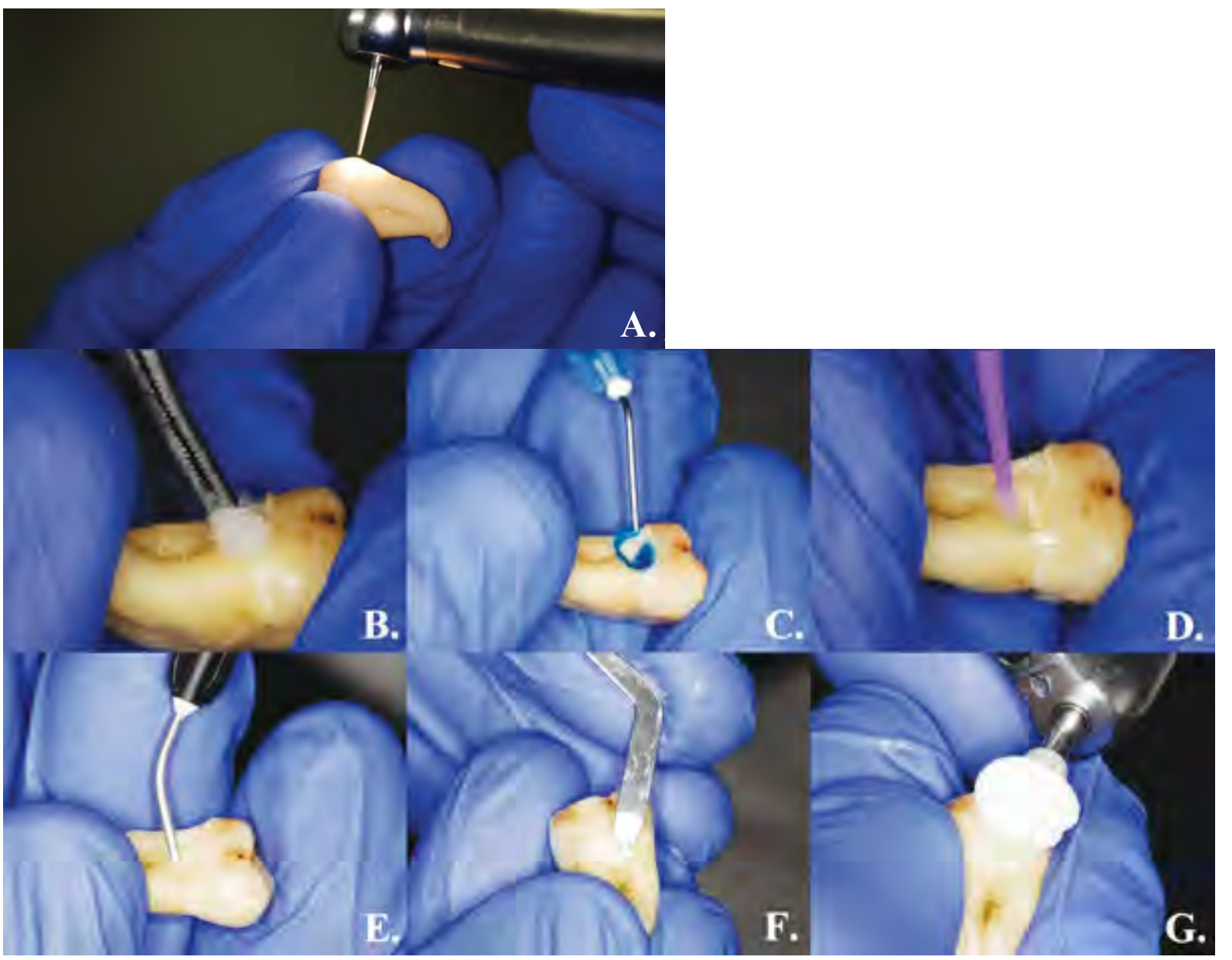

FIGURA 4. Protocol de lucru A. Prepararea cavităţii B. Toaleta cavităţii C. Demineralizare D. Aplicare răşină adezivă E. Aplicare strat intermediar (Grup 2 şi Grup 4) F. Aplicare compozit G. Finisare obturaţie
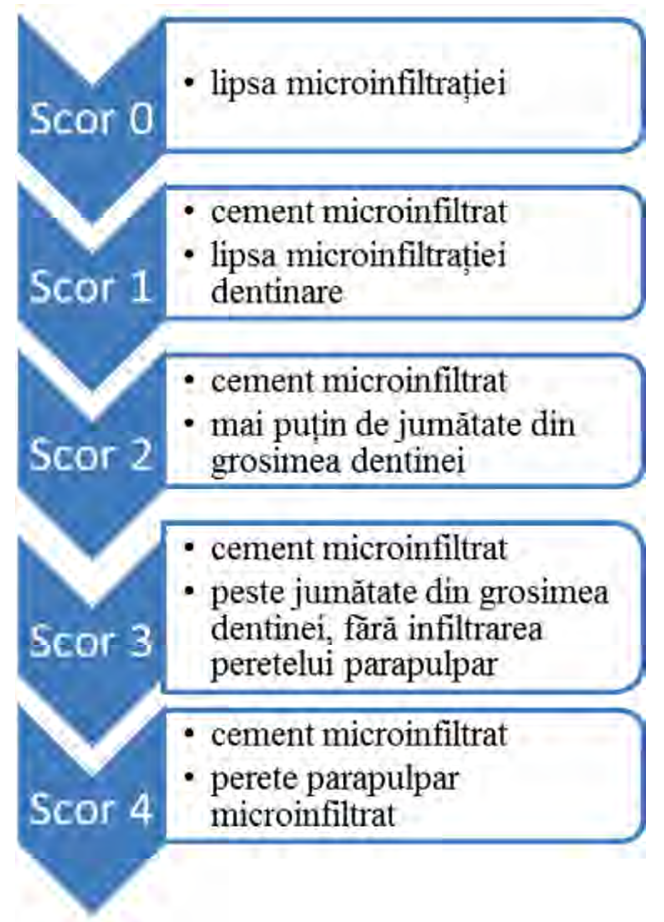

Polisher - Buehler). S-au ales secţiunile la care s-a observat cea mai mare penetrare a trasorului chimic pentru a fi analizate la microscopul optic cu lumină polarizată (AxioImager A1m - Zeiss). Pe baza analizei, s-a alcătuit o scară pentru a interpreta gradul penetrării albastrului de metilen la nivelul interfeţei dinte-obturaţie (Fig. 5).

\section{REZULTATE}

Rezultatele gradului de microinfiltraţie pentru fiecare grup sunt prezentate în Tabelul 1.

TABEL 1. Scoruri microinfiltraţie marginală

\begin{tabular}{|c|c|c|c|c|}
\hline Grup & Scor maxim & Scor minim & Scor mediu & Scor total \\
\hline Grup 1 & 2 & 1 & 1,5 & 9 \\
\hline Grup 2 & 2 & 1 & 1,3 & 8 \\
\hline Grup 3 & 2 & 1 & 1,8 & 11 \\
\hline Grup 4 & 2 & 2 & 2 & 12 \\
\hline
\end{tabular}

FIGURA 5. Scara gradului de penetrare a trasorului chimic 


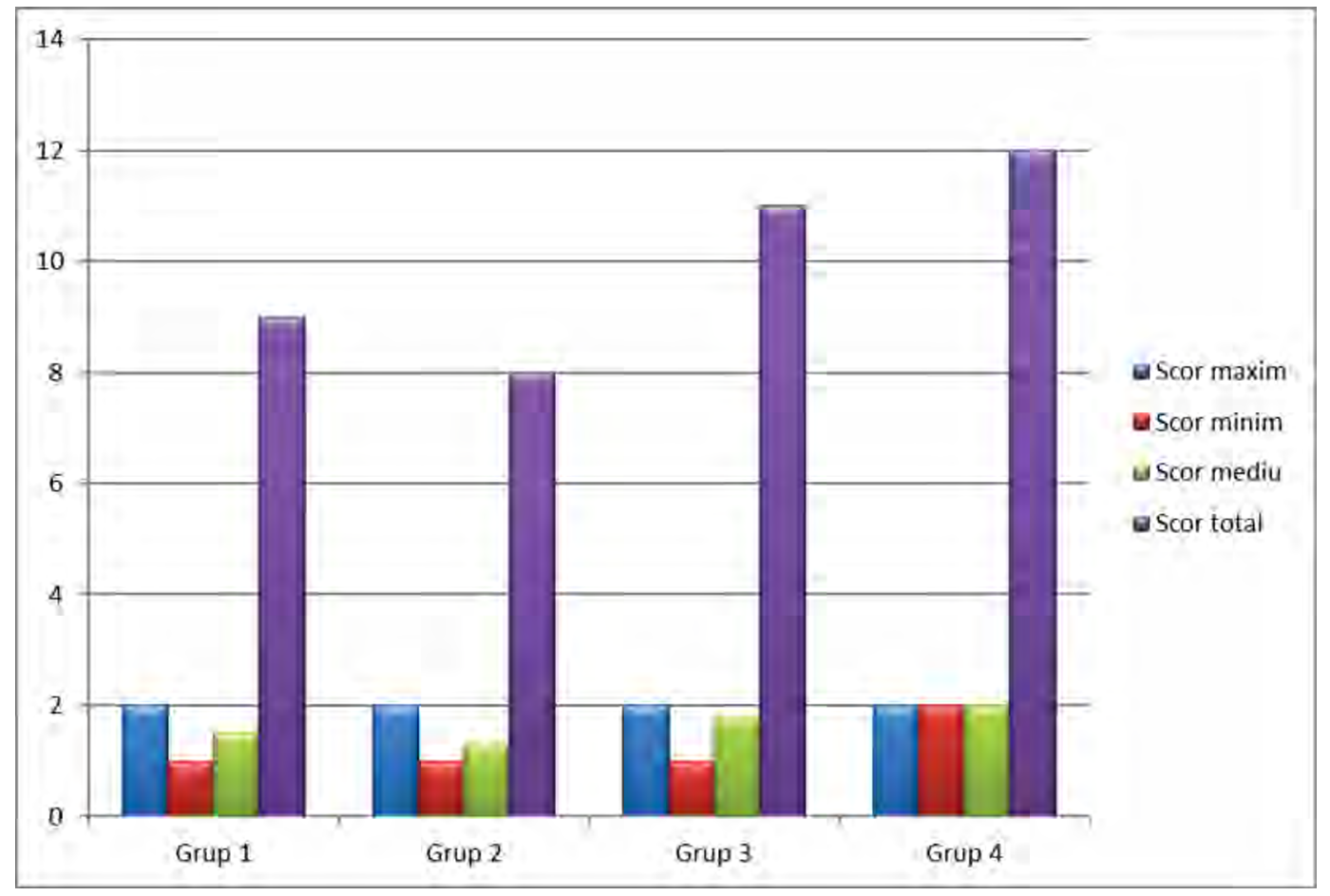

FIGURA 6. Grafic distribuţie scoruri microinfiltraţie marginală

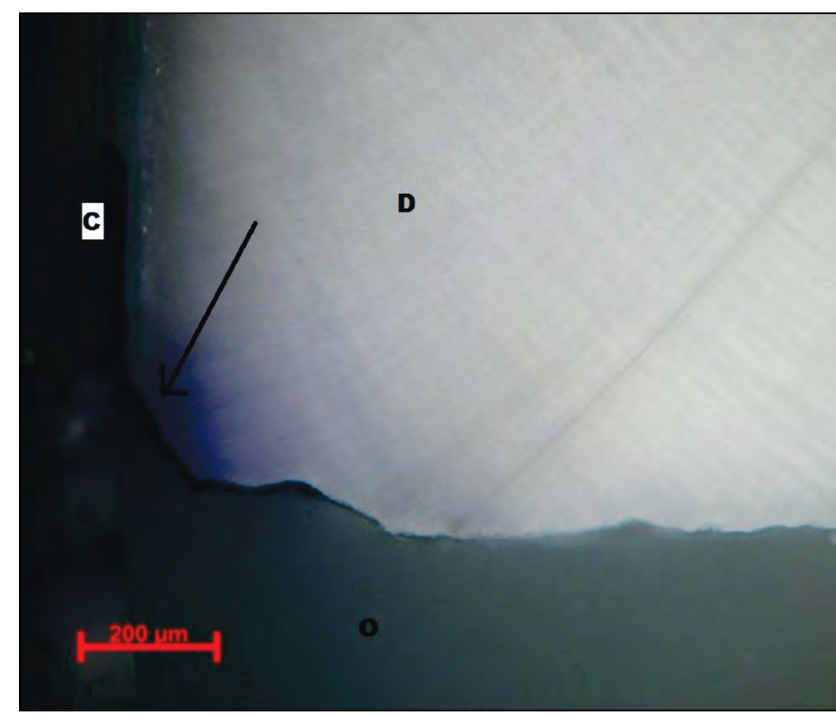

FIGURA 7. Grup 1. Secţiune microscopică la nivelul peretelui gingival al cavitătii. Se observă cementul (C) puternic infiltrat cu albastru de metilen (săgeată), care permite microinfiltraţia dentinei $(D)$ pe o distanţă mai mică decât jumătate din grosimea acesteia. $\mathrm{O}$ - obturaţie (lumină polarizată cu nicoli încrucişaţi)

\section{DISCUŢII}

Cavităţile clasa a V-a, în special cele ale căror limite depăşesc joncţiunea smalţ-cement, sunt predispuse eşecului din cauza microinfiltraţiei marginale. Cementul, bogat în substanţe organice, nu permite obţinerea unei adeziuni eficiente, restaură-

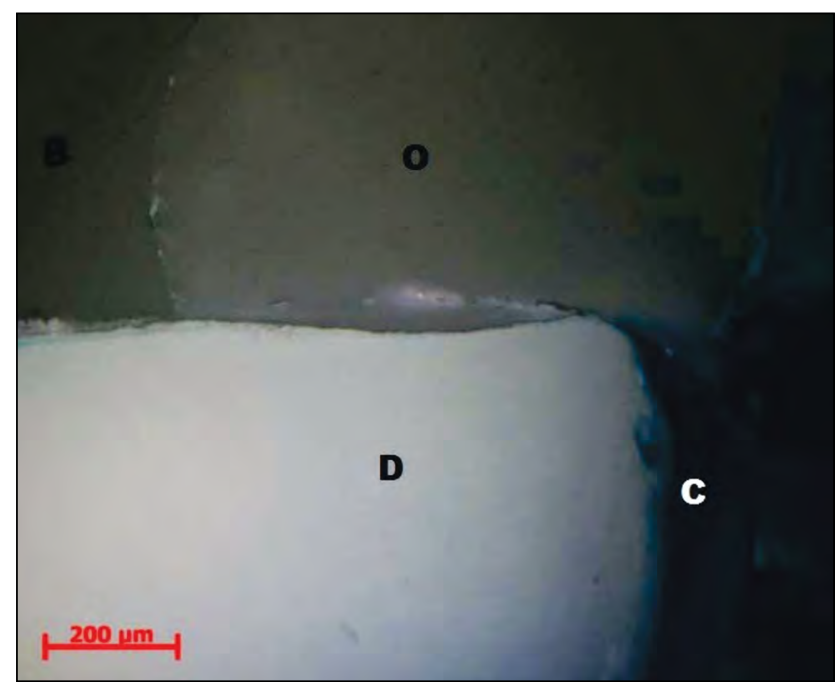

FIGURA 8. Grup 2. Secţiune microscopică la nivelul peretelui gingival al cavităţii. Se observă cementul infiltrat (C), care însă nu permite infiltraţia dentinei (D). Diferenţa de contrast dintre obturaţie $(O)$ şi obturaţie de bază $(B)$ este dată de densitatea diferită a materialelor (lumină polarizată cu nicoli încrucişaţi)

rile directe din răşini diacrilice compozite fiind în continuă dezvoltare pentru a contracara acest neajuns.

În prezent, literatura de specialitate oferă date asemănătoare prezentului studiu în ceea ce priveşte microinfiltraţia la nivelul cementului. Cercetarea efectuată de Sooraparaju SG, Kanumuru PK et al. (19) pe un număr de 30 de dinţi extraşi arată faptul 


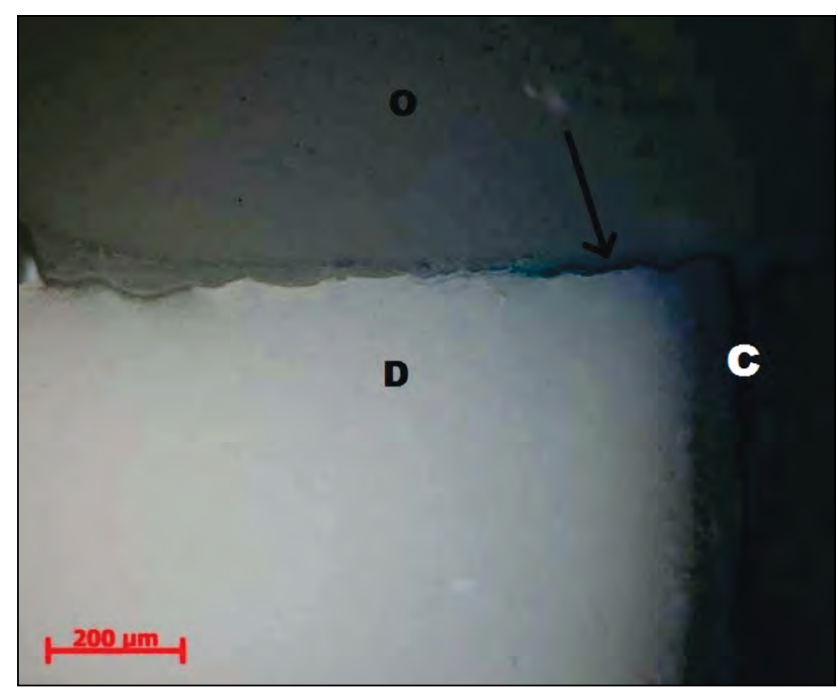

FIGURA 9. Grup 3. Secţiune microscopică la nivelul peretelui gingival al cavităţii. Cementul (C) este infiltrat în totalitate, permiţând şi infiltrarea dentinei $(D)$ pe o distanţă redusă (săgeată). O - obturaţie (lumină polarizată cu nicoli încrucişaţi)

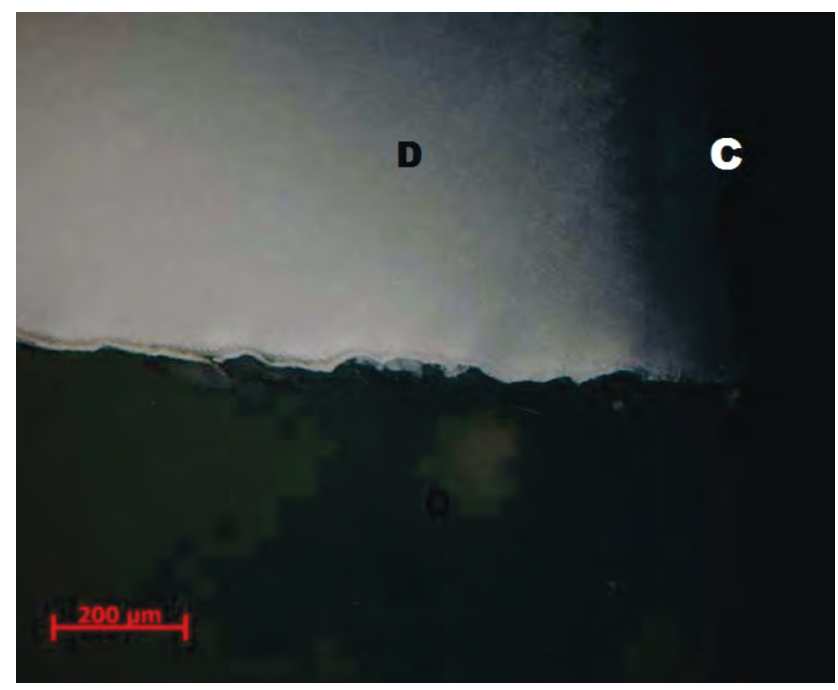

FIGURA 10. Grup 4. Secţiune microscopică la nivelul peretelui gingival al cavităţii. Infiltraţia cementului (C) şi a dentinei (D) la mai puţin de jumătate din grosimea acesteia. O - obturaţie (lumină polarizată cu nicoli încrucişaţi)

că răşinile diacrilice compozite nanohibride permit microinfiltraţie la nivelul limitei apicale a cavităţilor clasa a V-a, indiferent de prezenţa sau absenţa unui strat intermediar. De asemenea, Zavattini A, Mancini M et al. (20) observă aceeaşi situaţie în cazul compozitelor microhibride. Studiul de faţă se aliniază la concluziile majorităţii cercetătorilor, observându-se microinfiltraţii de diferite grade la nivelul tuturor celor 24 specimene. Cementul este infiltrat în toate cazurile în totalitate, semn al unei adeziuni inexistente, în timp ce dentina în doar 16 cazuri. Acest lucru este explicat de faptul că adezi- unea la nivelul dentinei este un proces complex, sensibil, datorat în principal prezenţei limfei din tubulii dentinari ce se deplasează spre suprafaţă în urma preparării şi împiedică formarea unui strat adeziv eficient (21).

Contracţia de polimerizare constituie cauza principală a microinfiltraţiei marginale. Contracţia induce stres la nivelul interfeţei dinte-obturaţie, ceea ce conduce la apariţia unui spaţiu la acest nivel, ulterior colonizat cu bacteriile din salivă. Printre factorii ce influenţează gradul contracţiei de polimerizare se regăsesc forma şi dimensiunea cavităţii, localizarea marginilor, dar şi tipul, cantitatea şi tehnica de polimerizare a materialului (22).

Răşinile diacrilice compozite utilizate în prezentul studiu sunt hibride, având o contracţie de polimerizare mai redusă decât cea a compozitelor convenţionale. Astfel, Filtek Z-250 (microhibrid) prezintă o rată a microinfiltraţiei marginală mai redusă la nivelul peretelui gingival al cavităţii, observându-se o medie a scorurilor de 1,5 (Grup 1), respectiv 1,3 (Grup 2). În contrast, dinţii obturaţi cu Filtek Z-550 (nanohibrid) au prezentat medii ale scorurilor de microinfiltraţie de 1,8 (Grup 3) şi 2 (Grup 4), niciun specimen neavând doar cementul afectat. Aceste rezultate sunt în concordanţă cu studii din literatura de specialitate. Cercetarea efectuată de Sharafeddin F, Koohpeima F şi Palizian B (23) pe 45 premolari extraşi a concluzionat faptul că răşinile diacrilice compozite microhibride permit o microinfiltraţie mai redusă decât cele nanohibride şi o diferenţă nesemnificativă faţă de compozitele pe bază de silorani. Există, de asemenea, şi rezultate în dezacord cu aceste concluzii $(14,15)$.

Existenţa unui strat intermediar între dinte şi obturaţia coronară, cu o rigiditate scăzută, aşa cum este cazul compozitelor fluide, creşte complianţa substratului adeziv. Un alt avantaj al acestei tehnici este faptul că distribuţia tensiunii este mai uniformă de-a lungul unui material cu modul de elasticitate redus, micşorând astfel riscul de microinfiltraţie marginală (24). De asemenea, o cantitate mai redusă de răşină diacrilică de consistenţă chitoasă va avea o contracţie de polimerizare mai redusă.

Gradia Direct LoFlo (GC) a fost folosit ca strat intermediar în studiul de faţă. Comparând rezultatele dintre grupurile cu obturaţie de bază (G2 şi G4) şi cele fără (G1 şi G2), se remarcă faptul că nu există diferenţe semnificative între acestea. Se observă 
o egalitate aproape perfectă între grupurile obturate cu compozit nanohibrid, G3 şi G4, în timp ce între cele obturate cu compozit microhibrid (G1 şi G2), decalajul este minim. Alireza Boruziniat et al. (25) realizează o analiză sistematică a 18 studii privind importanţa existenţei unui strat intermediar în contracararea microinfiltraţiei marginale. Rezultate indică lipsa îmbunătăţirii performanţelor clinice şi a adeziunii. Literatura de specialitate citează, de asemenea, rezultate asemănătoare $(26,27)$, însă şi în contradicţie cu studiul prezent $(16,17)$, astfel reieşind necesitatea unor studii ample, semnificative, şi a unor rezultate unitare.

Deşi niciun specimen studiat nu a fost lipsit de microinfiltraţie marginală, rezultatele sunt satisfăcătoare. Niciun dinte nu a prezentat un scor mai mare de 2 (afectarea cementului şi a dentinei pe mai puţin de jumătate din grosime), ceea ce sugerează o adeziune modestă la nivelul dentinei. $\mathrm{Cu}$ toate acestea, se impune dezvoltarea unor soluţii pentru perfecţionarea adeziunii la nivelul cementului şi dentinei. Cercetările în domeniu au arătat faptul că tratarea cementului cu soluţie de hipoclorit de sodiu $10 \%$, activat prin frecare, anterior acţiunii

\section{BIBLIOGRAFIE}

1. Tziafas D, Eliades G. Strategies for Bonding to Root Dental Structures. In: Eliades G, Watts D, Eliades T, editors. Dental Hard Tissues and Bonding. Berlin: Springer-Verlag; 2005.

2. Mantri SP, Mantri SS. Management of shrinkage stresses in direct restorative light-cured composites: A review. J Esthet Restor Dent. 2013;25:305-13.

3. Calheiros FC, Sadek FT, Braga RR, et al. Polymerization contraction stress of low-shrinkage composites and its correlation with microleakage in class V restorations. J Dent. 2004;32:407-12.

4. Hepdeniz OK, Ermis RB.Comparative evaluation of marginal adaptation and microleakage of low-shrinking composites after thermocycling and mechanical loading. Niger J Clin Pract. 2019;22(5):633-641.

5. Neiva IF, de Andrada MA, Baratieri LN, Monteiro S, Júnior, Ritter AV. $A n$ in vitro study of the effect of restorative technique on marginal leakage in posterior composites. Oper Dent. 1998;23(6):282-9.

6. Braga RR, Ferracane JL. Alternatives in polymerization contraction stress management. J Appl Oral Sci. 2004;12(Spe):1-11.

7. Sakaguchi R, Powers J. Craig's Restorative Dental Materials. 13th ed: Mosby; 2012. p. 135-45, 61-82, 327-33.

8. Ghavamnasiri M, Moosavi H, Tahvildarnejad N. Effect of centripetal and incremental methods in class II composite resin restorations on gingival microleakage. J Contemp Dent Pract. 2007;8(2):113-20.

9. Eliades $\mathrm{G}$, Palaghias $\mathrm{G}$, Vougiouklakis $\mathrm{G}$. Bonding composites to cementum by Gluma: surface characterization and bond strength. J Dent Res. 1991;70:383.

10. Abdulsalam RAZ, Miwan SAR, Shawbo MA. Effect of two different composites on gingival microleakage of class II restoration using four different placement techniques (an in vitro study). International Journal of Recent Advances in Multidisciplinary Research. 2015;02(09):0727-31. adezivului, determină reducerea procentului de substanţe organice şi îmbunătăţirea adeziunii. De asemenea, o altă modalitate constă în folosirea laserului, însă există un număr restrâns de studii în acest sens şi, în plus, se consideră că adezivii actuali pot fi afectaţi de acţiunea laserului (1).

\section{CONCLUZII}

$\mathrm{Cu}$ toate limitele prezentului studiu, se poate concluziona faptul că obturaţiile de compozit permit microinfiltraţia cementului şi dentinei, ducând în timp la posibilitatea eşecului restaurării directe. De asemenea, existenţa unui strat intermediar din compozit fluid nu ameliorează adeziunea.

Aşadar, se impune derularea unor cercetări viitoare ample, detaliate, care să evidenţieze modalitatea de obţinere a unei adeziuni optime la nivelul cementului şi dentinei.

\section{Notă}

Toţi autorii au contribuit în mod egal la realizarea acestui studiu.

Conflict of interest: none declared Financial support: none declared

11. Pereira RA, Araujo PA, Castaneda-Espinosa JC, Mondelli RF. Comparative analysis of the shrinkage stress of composite resins. Journal of Applied Oral Science: revista FOB. 2008;16(1):30-4.

12. Dalli M, Bahsi E, Sahbaz C, Ince B, Akkus Z, Ercan E, et al. A Comparison of Microleakage Scores of Five Different Types of Composite Resins. Biotechnology \& Biotechnological Equipment. 2010;24(4):2122-6.

13. Bagis $\mathrm{YH}$, Baltacioglu IH, Kahyaogullari S. Comparing microleakage and the layering methods of silorane-based resinc omposite in wide Class II MOD cavities. Operative Dentistry. 2009;34(5):578-85.

14. Yarmohamadi E, Jahromi P, Akbarzadeh M. Comparison of Cuspal Deflection and Microleakage of Premolar Teeth restored with Three Restorative Materials. J Contemp Dent Pract. 2018;19(6):684-9.

15. Saumya., Dhingra R, Gupta A, Karunanand B. Comparative Evaluation of Fracture Resistance and Microleakage of Reattached Anterior Tooth Fragment Using Two Different Flowable Composites - An in vitro Study. British Journal of Medicine and Medical Research. 2017;21:1-10.

16. Tung FF, Estafan D, Scherer W. Microleakage of a condensable resin composite: An in vitro investigation. Quintessence Int. 2000;31:430-4.

17. Leevailoj C, Cochran MA, Matis BA, Moore BK, Platt JA. Microleakage of posterior packable resin composites with and without flowable liners. Oper Dent. 2001;26:302-7.

18. Chuang SF, Jin YT, Lin TS, Chang CH, García-Godoy F. Effects of lining materials on microleakage and internal voids of class II resin-based composite restorations. Am J Dent. 2003;16:84-90.

19. Sooraparaju SG, Kanumuru PK, Nujella SK, Konda KR, Reddy KB, Penigalapati S. A comparative evaluation of microleakage in class $\mathrm{V}$ composite restorations. Int J Dent. 2014;2014:685643.

20. Zavattini A, Mancini M, Higginson J, Foschi F, Pasquantonio G, Mangani F. Micro-computed tomographye valuation of microleakage 
of class II composite restorations: An in vitro study. Eur J Dent. 2018;12(3):369-374.

21. Nicholson JW. The Chemistry of Medical and Dental Materials. Cambridge: RSC Materials Monographs; 2002, p. 149-58.

22. de Oliveira Araujo F, Vieira LC, Monteiro Junior S. Influence of resin composite shade and location of the gingival margin on the microleakage of posterior restorations. Oper Dent. 2006;31:556-61.

23. Sharafeddin F, Koohpeima F, Palizian B. Evaluation of Microleakage in Class V Cavities Filled with Methacrylate-based versus Siloranebased Composites. J Dent Biomater. 2015;2(2): 67-72.

24. Yazici AR, Baseren M, Dayangaç B. The effect of flowable resin composite on microleakage in class $\mathrm{V}$ cavities. Operative Dentistry. 2003;28(1):42-46.
25. Boruziniat A, Gharaee S, Sarraf Shirazi A, Majidinia S, Vatanpour M. Evaluation of the efficacy of flowable composite as lining material on microleakage of composite resin restorations: A systematic review and meta-analysis. Quintessence Int. 2016;47:93-101.

26. Neme AM, Maxson BB, Pink FE, Aksu MN. Microleakage of class II packable resin composites lined with flowables: An in vitro study. Oper Dent. 2002;27:600-5.

27. Arslan S, Demirbuga S, Ustun Y, Dincer AN, Canakci BC, Zorba YO. The effect of a new-generation flowable composite resin on microleakage in class $\mathrm{V}$ composite restorations as an intermediate layer. J Conserv Dent. 2013;16:189-93. 